\title{
Voimme arvostaa teoreetikkojamme perehtymällä heidän näkemyksiinsä ja arvioimalla niitä
}

\author{
Urpo Harva pitäytyi jokseenkin Zachris Castrénin viitoit- \\ tamalla aikuiskasvatuksen linjalla kansansivistystyön \\ teorianmuodostuksessa, päättelee Timo Toiviainen pu- \\ heenvuorossaan aikuiskasvatuksen klassikoistamme. \\ Toiko Harva aikuiskasvatuspedagogiikkaan uutta ja \\ omaa ja jos, niin mitä?
}

\begin{abstract}
A ikuiskasvatuksen numerossa 3/2001 Camila Kovero kysyy, onko Suomen aikuiskasvatus murrosvaiheessa. Hän tarkastelee aihetta käsittelemällä ajankohtaisia historiallisia ja uudempia (moderna) aikuiskasvatuskysymyksiä. Jotta keskustelu tästä tärkeästä aiheesta jatkuisi, esitän muutamia näkökohtia ja lisäjuonteita.

En malta kuitenkaan olla toteamatta aluksi jotain Camilla Koveron artikkelissa huomiotani kiinnittäneitä yleisiä seikkoja.
\end{abstract}

\section{Luotettavuus ja lähteet}

Camilla Kovero on käsitellyt aihettaan laajan lähdeaineksen perustalta. Koska eräät hänen artikkelinsa osiot olivat erityisen kiintoisia, halusin mennä syvemmälle tekstin taustaan. Osa noin sadasta kirjoituksen viitteestä on luonteeltaan sellaisia, ettei niissä tarvita sivunumeroita. Kun sivut on ilmoitettu kuitenkin vain noin kahdessakymmenessä viitteessä sadasta, oli työlästä tai mahdotonta tutustua lähemmin osaan taustamateriaalia, vaikka sen pitäisi juuri lähdesysteemin avulla olla mahdollista.

Kirjoittaja ilmoittaa tekevänsä analyysinsä nojautuen keskeisten alan ajattelijoiden kirjoituksiin. Näin hän ei kuitenkaan menettele systemaattisesti. Metodologisesti on kiusallista, ettei lähteenä ole käytetty aivan keskeisiäkään alan dokumentteja tai johtavien ajattelijoiden kirjoituksia tai ettei niitä ole riittävästi hyödynnetty, vaikka ne lähdeluettelossa mainitaankin. Palaan myöhemmin tähän kysymykseen.

Sinänsä jo lähdeaineksen valinta kertoo siitä, että Camilla Kovero tuntee vain osittain teemansa historiallisen osuuden vaikuttajien aatehistoriallista taustaa ja tuotantoa. Valitettavaa on myös se, ettei hän arvioi kriittisesti käsittelemiensä vaikuttajien teorioita ja kannanottoja. Esitykseen tulee epähistoriallinen leima, koska kirjoittaja ei liitä mitenkään yhteen keskeisten vaikuttajien työtä. Tästä syystä hänen laajasta kirjoituksestaan jäävät puuttumaan ristiriidat ja muut sellaiset dynaamiset ainekset, jotka tekevät historiallisesta analyysistä mielenkiintoisen ja joita aina on myös kasvatuskysymyksistä kirjoitettaessa.

Artikkelin näkökulmana on miltei yksinomaan yleissivistävä aikuiskasvatus. Ammatillieen aikuiskoulutuksen kirjoittaja siis sivuuttaa muutamalla maininnalla. Puuttumatta sinänsä mielestäni oleelliseen kysymykseen siitä, mikä on ammatillisen aikuiskoulutuksen osuus aikuiskasvatuksen yleisen teoriaperustan laajentumisessa ${ }^{1}$, jatkan Koveron artikkelin inspiroimana keskustelua aikuiskasvatuksen klassikoista.

\section{J.V. Snellman - suotuisan sivistysilmapiirin filosofi}

amilla Kovero siteeraa J.V. Snellmanin teoksesta LÄRAN OM STATEN lausumaa koulutuksesta 
ja tasa-arvosta (Kovero 2001). Snellmanin lause voidaan tulkita siten, että Snellman olisi kannattanut laajaa yhteiskunnallista ja sivistyksellistä tasaarvoa. Kovero tukeutuu alkuperäislähteen lisäksi myös Viljo Rasilan artikkeliin (Rasila 1989, 2526), jossa puhutaan samasta Snellmanin kannanotosta ja jossa nähdään sidos Snellmanin ja tasaarvokysymysten välillä.

Se, miten Snellman kaiken kaikkiaan mielsi tasa-arvokysymykset, on kuitenkin monitahoinen asia ja sitä on tarkasteltava historiallisessa kehyksessään. Rainer Aaltonen käsitteli eräitä Snellmanin ajattelun puolia Aikuiskasvatuksen palstoilla kaksi vuosikymmentä sitten. Hänen artikkelistaan (Aaltonen 1981, 45-50) käy ilmi se, että Snellmanin yhteiskuntakuva oli selkeän sääty-/ luokkajakoinen ja että se tarkoitti ensisijassa valmentautumista kullekin säädylle kuuluviin tehtäviin. ${ }^{2}$ Kari Palonen tulkitsee Snellmania niin, että tasa-arvoisuus käsitetään [Snellmanin ajattelussa] ahtaasti tasa-arvoisuudeksi lain edessä sekä vaatimukseksi rahvaan sivistystason kohottamisesta (Palonen 1975, 29). Omat 'Snellman-opintoni' ovat vasta alkuasteella, mutta siltä osin kuin olen Snellmanin tuotantoon ehtinyt paneutua, olen taipuvainen olemaan samalla kannalla kuin Palonen.

Tässä yhteydessä ei ole mahdollista ryhtyä käymään laajempaa keskustelua Snellmanin kasvatusajattelusta (josta valmistui viime vuonna Taina Sylvanderin lisensiaatintutkielma). Kiintoisana vertailukohtana voi kuitenkin ottaa huomioon sen seikan, että kun Ukko-Grundtvig vähän Snellmanin toimintaa aikaisemmin suunnitteli uutta 'koko kansan' oppilaitosta, kansanopistoa, ei hän aluksi lukenut naisia kansaan kuuluviksi (Wilska 1936, 9). Eräät hänen ideaansa hurahtaneet alkoivat kuitenkin vaatia myös tytöille pääsyä kansanopistoon, ja tässä kysymyksessä teologi-runoilija Grundtvigin selkä osoittautui taipuisaksi (ibid. 18). Suomen vapaan sivistystyön historiassa tällä seikalla on oma merkityksensä. Sofia Hagman, naisasia-aktivisti Lucia Hagmanin sisar, innostui mm. Askovin kansanopistoon tekemällään opintomatkalla juuri tyttöoppilaiden hyvästä kohtelusta. Tämä kokemus oli omiaan rohkaisemaan Sofia Hagmania perustamaan Suomen ensimmäisen kansanopiston vuonna 1889 Kangasalle (Karttunen 1979, 16).

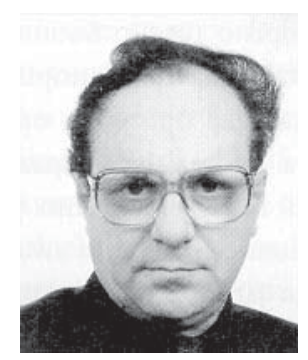

Timo Toiviainen

Hahmotan Snellmanin suomalaisen aikuiskasvatuksen historiassa filosofisen perustan luojana sellaiselle ajattelutavalle, joka tuki monia konkreettisia, sivistystyötä sen eri sektoreilla eteenpäin vieviä hankkeita. Näen selvää yhtäläisyyttä Snellmanin ja amerikkalaisen filosofin John Deweyn välillä. Molemmilla on omassa maassaan 'kansallisfilosofin' asema ja molemmat ottivat laajasti kantaa sivistyksellisiin kysymyksiin. Deweya on pidetty ehkä kaikkein merkittävimpänä elinikäisen oppimisen taustateoreetikkona ${ }^{3}$. Dewey-tutkija Robert B. Westbrook (1991, tittelisivulla oleva motto) toteaa, että tietoisuus kunkin aikakauden suhteesta Deweyyn merkitsee amerikkalaisille itsetutkiskelua siitä, mikä on heidän suhteensa itseensä. Olisiko tällä allegorialla käyttöä IT-Suomessa, jossa - taas kerran - on jouduttu hakemaan menestymisen perustaa osaamisen kautta sivistyksestä?

\section{Zachris Castrén - teorian ja käytännön yhdistäjä}

$\mathrm{Z}$ achris Castrén (1869-1938) oli omaksunut laajasti Snellmanin käsityksiä yhteiskunnasta yleensä ja sivistyksestä erityisesti. Castrén mm. toimitti kirjasen Snellmanin keskeisinä pitämistään ajatuksista. Castrénin kirjallinen päätyö oli hänen vuonna 1929 valtioneuvostolle laatima yhden henkilön komiteanmietintö Valtio ja vapaa kansansivistystyö. Sen puuttuminen Camilla Koveron käyttämistä lähteistä on pakottanut hänet turvautumaan toisen käden materiaaliin, mikä on johtanut hänet osin väärään tulkintaan. Koveron tekstistä saan sen käsityksen, että aikuiskasvatuksen suomalainen lähestymistapa ja käytäntö perustuvat englantilaiselle traditiolle. Kui- 
tenkin kansanopisto tuotiin Suomeen Tanskasta (Ruotsin kautta) sekä työväenopisto (nykyisen lain mukaan kansalaisopisto) ja opintokerhotoiminta Ruotsista. Suomalaisen vapaan sivistystyön traditio on siis mitä selkeimmin pohjoismaista juurta, josta sitten on kasvanut aivan omaleimainen kansallinen järjestelmä.

Kirjoittajan johtopäätös johtunee siitä, että hän tulkitsee väärin lähteitään ja ettei hän ole käyttänyt hyväkseen The 1919 Report -asiakirjaa. Se, missä määrin Castrén nojautui omassa mietinnössään tähän Englannissa laadittuun raporttiin, ei muuta suomalaisen sivistystyön pohjoismaista menneisyyttä eikä ennustanut mitään sen tulevaisuudestakaan. Pohjoismaisuus on ollut Castrénin mietinnön jälkeenkin suomalaisen aikuiskasvatuksen, erityisesti vapaan sivistystyön, lähin viiteryhmä.

Castrén on saanut oikeutetusti kuvansa suomalaisen sivistystyön kaapin päälle. Häntä kohtaan tunnettu perusteltu arvonanto on kuitenkin ehkä jättänyt varjoonsa kriittisiä näkökulmia. Otan yhden esimerkin. Castrén esittelee mietintönsä B-osassa 'Opintokerhot' Englannissa yliopistojen laajennusliikkeen käyttämää metodia 'tutorial classes' (Castrén 1929, 30) ikään kuin se olisi jonkinlainen opintokerhon varhaisin alkumuoto. Metodisesti se ei kuitenkaan ole rinnasteinen Oscar Olssonin kehittämälle opintokerhomallille. Tällainen mallin lainaaminen olisi ollut sitä paitsi mahdotontakin, koska Olsson esitteli kerhometodin vuonna 1902, mutta ensimmäiset tutorial classes -ryhmät kokoontuivat vasta vuonna 1907 (The 1919 Report, 191). Näin ollen on johdonmukaista, että Peter Jarvis, joka varmasti tietää, mikä on opintokerho- ja tutorial classes - metodin ero ja historiallinen syntyjärjestys, antaa kunnian opintokerhometodin luomisesta yksin Oscar Olssonille (Jarvis, 1990, 250-251, 345-346).

$\mathrm{C}$ astrén oli taustaltaan filosofi. Hän oli kuitenkin lähestymistavoiltaan käytännöllinen. Hän loi mietinnöllään ja muulla kirjoittelullaan sekä sivistysjärjestöjohtajana ja Yhteiskunnallisen Korkeakoulun kansansivistysopin opettajana teoreettista ja käytännöllistä perustaa suomalaiselle sivistystyölle. Kestävintä hänen toiminnassaan oli valtion ja sivistystyön suhteen määrittäminen.

\section{Urpo Harva - kiistanalainen filosofi ja keskustelija}

$\mathrm{K}^{\mathrm{a}}$ äsitellessään Urpo Harvan (1910-1994) meritystä Camilla Kovero pitää tämän pienimuotoista kirjasta (76 s.) Vapaa kansansivistystyö (1943) tärkeänä etappina (suomalaisen) aikuiskasvatuksen teorianmuodostuksessa. Vaikka Kovero mainitsee kirjasen lähdeluettelossaan, hän ei käytä sitä arvioidakseen ja sanoakseen, m i k s i Harvan kirjanen on tärkeä. Voimme kuitenkin antaa Harvalle itselleen puheenvuoron.

Vapaan kansansivistystyön esipuheessa (s. 6-7) Harva totesi mm.: "Tässä tutkielmassa - kuten jo sen suppeudesta on pääteltävissä - ei ole tarkoitus kehitellä vapaan kansansivistystyön teoriaa kaikilta mahdollisilta puolilta. Tutkielmassa otetaan puheeksi vain yksi asia ... Tässä tarkoituksessa vapaa kansansivistystyö asetetaan yhteyteen erään todellisuuden suuremman osan, nimittäin kasvatuksen maailman kanssa. ... Vapaa kansansivistystyö olisi näin ollen kasvatuksen maailman elimellinen osa ja sen teoria olisi osa kasvatuksen teoriasta." Tämän jälkeen lukijan ei tarvitse odottaa Harvan tutkielmalta enempää, kuin mitä tekijä pyrkii tarjoamaan. Mutta antihan on, jos tehtävä on onnistunut, merkittävä askel teorianmuodostuksessa. Puheena olevassa kirjasessa, samoin kuin muussakin tuotannossaan, Harva kuitenkin pitäytyy jokseenkin Castrénin viitoittamalla aikuiskasvatuksen linjalla.

Käsitykseni mukaan Aulis Alanen tunsi tieteellisen arvioinnin näkökulmasta parhaiten arvostamansa opettajan Urpo Harvan ajattelua ja tuotantoa, vahvuuksia ja heikkouksia. Näitä kaikkia puolia Alanen käsittelee mm. Urpo Harva symposiumin julkaisussa (1997, 27-36). Hän näkee Harvan ansiot teorian kehittäjänä ja filosofina sekä pitkäaikaisena akateemisena opettajana. Harvan persoonan luonnehdinta jäisi vajaaksi, ellei siinä ottaisi huomioon rohkeaa ja intohimoista keskustelijaa.

Jos näemme Jukka Tuomiston lailla sivistyksellisen tasa-arvon edistämisen suomalaisen aikuiskasvatuksen "suurena linja" (Tuomisto 1989, 31-56), joudumme toteamaan, ettei Urpo Harva ollut tuon linjan tukija. Hänellä oli ihmislajin pitkän aikavälin kehityksestä pessimistinen käsitys. Tasa-arvokysymykset saivat muutoin ratio- 
naalisen Harvan toisinaan suunniltaan, mikä ilmeni monista hänen julkisista kannanotoista. Harvassa on vahvaa ristiriitaisuutta. Toisaalta hän on valmis myöntämään, että demokratisoituminen ei ole vienyt eteenpäin ainoastaan yleisen kansanopetuksen, vaan myös aikuiskasvatuksen aatetta (Harva 1958, 24), mutta toisaalla hän asettuu avoimesti kansanvallan laajaa soveltuvuutta vastaan. Yliopistojen hallinnonuudistuksen johdosta laatimassaan pamfletissa (Harva 1969, 6) hän totesi mm.: "Demokratian periaatteet eivät näet sovi kaikkiin ihmisten välisiin suhteisiin eikä kaikkien yhteisöjen ja instituutioiden tarkoitus ole demokratian levittäminen." Ottaen huomioon reaalimaailman Harvan tässä äärimmäisessä kannanotossa voi nähdä jotakin hyväksyttävääkin. Harvaa lähemmin tuntematon saattaa perustellusti kysyä, miten demokratiaan ja tasaarvopyrkimykseen vähätellen, jopa halventavasti suhtautuva henkilö saattoi toimia kansansivistysopin opettajana ja oppituolin haltijana. Harva saattoi, tällainen ristiriitaisuus oli osa hänen persoonaansa.

Olen aikaisemmin (Toiviainen 1997, 45-76) selvittänyt niitä kansainvälisiä vaikutteita, jotka ovat nähtävissä Urpo Harvan kirjallisessa tuotannossa. Siinä yhteydessä jouduin toteamaan, että Harvan tapa operoida käsitteillä ja käyttää lähteitä ei ole kaikilta osin hyväksyttävää. Eräänä ongelmana on pidettävä sitä, että hän samaisti englannin kielen käsitteen 'adult education' suomen kielen käsitteeseen 'vapaa (kansan)sivistystyö'. Tämä samastus salli hänen tehdä sellaisia vertailuja ja rinnastuksia, jotka olivat vailla todellisuuspohjaa. Myös se, että hän teki toisinaan kovin myönteisiä johtopäätöksiä ulkomaisista käytänteistä pelkästään kirjallisten lähteiden perusteella, saattoi vääristää asioita.

Väitöskirjansa Suomalaisen kulttuurifilosofian vuosisata johdannossa Mikko Salmela (1998, 2021) perustelee, miksi hän on valinnut tutkimuksensa kohteeksi tietyt filosofit ja miksi jättänyt muut ulkopuolelle. Urpo Harvan tutkijanlaadusta Salmela toteaa, että Harvan laaja tuotanto on lähinnä toisten ajattelijoiden näkemyksiä selostavaa ja kritisoivaa. Tätä Harvan tuotannon pääalueeseen eli filosofian alan tuotantoon mahdollisesti sopivaa arviota ei voida siirtää koskemaan hänen kasvatusalan tuotantoaan. Harvan pääteos Systemaattinen kasvatustiede (1960) on omaperäinen hahmotus kasvatustieteestä. Mutta kirja käsittelee kasvatustiedettä yleisesti. Sen suoranainen anti aikuiskasvatukselle jää niukaksi. Harva vei aikuiskasvatuksen teoriaa omalta osaltaan eteenpäin tutkielmallaan Vapaa kansansivistystyö, sen ajantasaistetulla ja asioita osin uudelleen hahmottaen kirjasellaan Aikuiskasvatus. Johdatus aikuiskasvatuksenteoriaanjatyömuotoihin Suomessa (1958) sekä laajalla artikkelituotannollaan. Akateemisena opettajana hän vaikutti syvästi laajaan oppilasjoukkoon, niihinkin, jotka eivät hyväksyneet hänen kaikkia näkemyksiään.

\section{Aulis Alanen - komitea- laitoksen sankari ja uhri}

ulis Alanen (1929-1998) on saanut Camilla
Koveron artikkelissa ansaittua huomiota. Omalta osaltani haluan tuoda esiin Aulis Alasen elämäntyöstä erään lisän, joka on mielestäni syytä muistaa häntä arvioitaessa. Aulis Alasella lienee nimittäin hallussaan omalla sektorillaan komitea-, toimikunta- tai työryhmäsihteeriyden Suomen ennätys. En tiedä ketään, joka olisi ollut häntä enemmän eri ryhmien sihteerinä 1960ja 1970-luvulla. Etenkin nuoremman lukijapolven on tässä yhteydessä hyvä ottaa huomioon, että tuolloin, ja osin vielä 1980-luvun alussakin, eri asioita kehitettiin kovin 'valtiojohtoisesti'. Se, mitä komiteoissa, toimikunnissa ja työryhmissä saatiin aikaan, näkyi usein aivan konkreettisestikin rahana valtion budjetissa. Ennen lamaahan oli rahaa, mitä jakaa, ja se oli vaikuttaja, joka pääsi jakopolitiikkaa suunnittelemaan.

Mutta tieteenharjoittajalle asialla on nurjakin puolensa. Eri ryhmissä työskentely vie aikansa, ja muu kirjoittelu ja henkilökohtainen meritoituminen jäävät vähemmälle tai kokonaan sivuun. Aulis Alanen kirjoitti monien mietintöjen tekstiluonnokset, mutta komitean työ on aina kollektiivista, eikä sitä voi kukaan omiin nimiinsä merkitä.

Myönteisesti asiaa arvioiden oli tietenkin suomalaisen aikuiskasvatuksen onni, että alan monilla työryhmillä oli käytettävissään Alasen tapainen voimavara, jonka poikkeuksellinen ammattitaito saattoi juuri työryhmien kautta päästä 
hyödyttämään koko aikuiskasvatusjärjestelmää. Kysyttävä kuitenkin on, jäikö Alaselta sitten vastaavasti jotakin muuta tekemättä, kun sihteeriydet veivät paljon hänen aikaansa.

Omimmillaan Aulis Alanen oli eri työryhmienkin työssä silloin, kun hän kirjoitti didaktisista kysymyksistä; niitä koskeviin tekstiluonnoksiin muilla ei tavallisesti ollut juuri mitään huomautettavaa. Alasella oli takanaan myös psykologian opinnot, ja niiden tarjoaman tietämyksen takia hänellä oli paljon annettavaa aikuisopetuksen didaktiikan teorian kehittämiselle. Nyt sekin anti näkyy ehkä pysyvimmin 'valtiollistetuissa' mietinnöissä ja tuntuu ehkä elävimmin hänen monissa oppilaissaan ammattitaitopääomana. Tietääkseni Alasen piti kirjoittaa didaktiikan alan kirja, mutta tätä hanketta hän ei ehtinyt toteuttaa. Se oli vahinko, jonka suuruus vain päivä päivältä kasvaa, kun vieläkään ei ole olemassa laajaa, korkeatasoista ja modernia alan perusteosta. Tämä seikka tekee luonnollisesti Jorma Ekolan ja Tapio Vahervan Aikuisopetusoppaasta (1980) ja Aikuisten opettamisen taidosta (1986) tärkeitä oppikirjoja. Matti Pelkosen vastaava yrityshän sai kovin nyreän vastaanoton (Virkkunen 1981, 7072).

Alasen kaksi opintokerho-/sivistysjärjestötyötä käsittelevää tutkimusta (Alanen 1969 ja 1986) ovat edelleenkin laadukkainta työtä, mitä kyseiseltä sivistystyön sektorilta on tehty. Kuvaavaa on, että sivistysjärjestöjen tehtäväkuvan muuttumista koskeva arviointitutkimuskin (1986) syntyi komitealaitoksen tilaamana. Camilla Kovero viittasi artikkelissaan paljon pitkään alan perusoppikirjana käytettyyn Alasen Johdatusta aikuiskasvatukseen (1985). Eräiltä osin sen antamaa kuvaa olisi täydentänyt Alasen toinen oppikirja Suomenaikuiskasvatuksenorganisaatiomuodot (1992).

\section{Ajanjaksojako toimii vain osittain}

K ysymys siitä, minkälaista ajanjaksojakoa olisi tarkoituksenmukaista käyttää Suomen aikuiskasvatuksen historiaa koskevissa kuvauksissa, on tärkeä. Historiallinen ajanjaksojako on mielekäs, mikäli kustakin ajanjaksosta voidaan löytää sellaisia tunnuspiirteitä, jotka erottavat kunkin jak- son sekä edellisestä että seuraavasta jaksosta. Jaksotuksen ongelmat eivät kuitenkaan välttämättä ole tunnuspiirteiden löytymisen jälkeen ratkaistu. Usein ongelmaksi tulee myös rajakohtien määrittäminen, koska historialliset ilmiöt alkavat ja loppuvat kunkin toiminnan oman dynamiikan mukaan kalentereista välittämättä.

Camilla Kovero viittaa oman ratkaisunsa yhteydessä Alasen (1985), Tuomiston (1989) ja Rasilan (1989) kirjoituksiin. Kuitenkin vain Rasila on käyttänyt käytännöllisesti katsoen samaa kehikkoa kuin Kovero eli jaksojakoa kansanvalistuksen, kansansivistyksen, kasvatuksen ja opetuksen aikaan. Ensimmäisen ajanjakson ja joten kuten toisenkin kohdalla jaksotus toimii, mutta sen jälkeen tulee selviä vaikeuksia niin tunnuspiirteiden kuin rajakohtienkin määrittämisessä. Vaikka Kovero ei kirjoitakaan aikuiskoulutuspolitiikasta, olisi hän ehkä saanut artikkeliinsa enemmän sidosta kunkin ajankohdan yhteiskunnalliseen tilanteeseen käyttämällä Alasen kehittelemää kolmijakoa suomalaisen aikuiskoulutuspolitiikan jaksoista 'myötäilevä sivistyspolitiikka, suunnittelukeskeinen aikuiskoulutuspolitiikka ja markkinaperusteinen aikuiskoulutuspolitiikka' (Alanen 1992, 10-15). Rinne ja Vanttaja $(1999,11)$ käyttävät sitä yhtenä lähtökohtanaan suomalaisen aikuiskoulutuspolitiikan 1980- ja 1990-luvun arviointitutkimuksessa, mutta se tarjoaisi näkökulmia myös varhempien vaiheiden analysointiin. - Päinvastoin kuin Kovero väittää (s. 222), opetushallituksella ei ole kokonaisvastuuta koulutuspolitiikasta; tämä vastuu on opetusministeriöllä.

\section{Saako kolmikko neljännen jäsenen?}

$\mathrm{M}$ ielenkiintoni tässä keskustelupuheenvuorossa on kohdistunut ennen muuta vapaan sivistystyön ja muun aikuiskasvatuksen kolmeen kehittäjään eli Castréniin, Harvaan ja Alaseen. Pitäisin ymmärrettävänä, jos joskus tulevaisuudessa, kun aikaetäisyys on riittävä, tutkimus liittäisi tuohon kolmen henkilön jatkumoon neljänneksi lenkiksi Jukka Tuomiston. Hän on kaikkein perusteellisimmin paneutunut aikuiskasvatustieteen siihen traditioon, jolta myös teorian uudista- 
mistyönkin on noustava. Ennen muuta tätä suvereenia alan hallintaa osoittavat hänen julkaisunsa Aikuiskasvatuksen perusaineksia (1992), jonka nimi on laatuun nähden kovin vaatimaton, sekä hänen artikkelinsa Suomalaisen aikuiskasvatustieteen perustanlaskijat:Zachris Castrén, Urpo HarvajaAulis Alanen (1998).

Sillä, jolle sovitetaan teorian kehittäjän takkia, pitää kuitenkin olla jotakin uutta sanottavaa. Nähdäkseni Tuomisto on ollut aikuiskasvatuksen alalla uranaukaisija kahdessa teemassa. Hän on käsitellyt suomalaisittain uudella ja uutta luovalla tavalla tasa-arvokysymyksen ja elinikäisen oppimisen teoriaperusteita useissa julkaisuissa (esim. Tuomisto 1989 ja 1997). Riippumatta siitä, tullaanko Jukka Tuomisto arvioimaan yhdeksi aikansa alan teorian kehittäjäksi, on sen, joka aikoo sanoa jotakin uutta hänen käsittelemistään pääteemoista, varauduttava tekemään paljon työtä.

\section{Tarvitsemme aikuis- kasvatuksen Ristijärven}

Kiinnitettyäni huomiota Jukka Tuomiston panokseen erään tradition jatkajana ja aikuiskasvatuksen kehittäjänä kiirehdin välittömästi toteamaan, että sitten Urpo Harvan 'yksinvallan' päivistä tilanne on täysin muuttunut. Tampereen lisäksi erityisesti Helsingin, Jyväskylän, Turun ja Lapin yliopiston piirissä on, kuten Camilla Koverokin toteaa, sellaisia yksikköjä, jotka ovat halunneet lähteä kehittämään aikuiskasvatustieteen eri alueita. Uudistan tässä yhteydessä Tapio Vahervan kuusi vuotta sitten tämän lehden palstoilla tekemän aloitteen siitä, että olisi parempi isommalla joukolla [yhdessä kuin eri asiantuntijat kukin omakohtaisesti] määritellä aikuiskasvatustieteen ja -tutkimuksen edistymisen tuntomerkit ja indikaattorit ja tällaiselta pohjalta suorittaa sitten alan tutkimuksen ja opetuksen arviointi (Vaherva 1995, 265-270).

Vahervan ehdotuksen taustalla oli kevättalvella 1983 Ristijärven pitäjässä järjestetty seminaari, jonka teemana oli "Onko kasvatustiede edistynyt?". Nyt alan edustajien olisi hyvä kokoontua pohtimaan, onko aikuiskasvatustiede edistynyt ja mitkä ovat sen edistymisen kriteerit nykyisin. Ajankohdaksi vuoden 2002 alkupuoli sopisi hyvin siksi, että noina aikoina kolme merkittävää alan oppituolin haltijaa, Seppo Kontiainen, Reijo Raivola ja Tapio Vaherva, on siirtymässä eläkkeelle. Aikuiskasvatuksen Tutkimusseura tahtonee harkita, olisiko aika panna toimeen aikuiskasvatuksen Ristijärvi. ${ }^{\text {II }}$

\section{Lähteet}

AALTONEN, R. (1981). Snellmanin oppi kasvatuksesta: lähtökohtia. Aikuiskasvatus 1 (1), 45-50.

ALANEN, A. (1969). Edistävä ja viihdyttävä opintokerhotoiminta. Acta Universitatis Tamperensis. Ser. A, vol. 29. Tampere: Tampereen yliopisto.

ALANEN, A. (1985). Johdatus aikuiskasvatukseen. Helsinki: Yleisradio.

ALANEN, A. (1986). Sivistysjärjestöjen tehtäväkuvan muuttuminen. Aikuis- ja nuorisokasvatuksen laitoksen julkaisuja. 23/1986. Tampere: Tampereen yliopisto.

ALANEN, A. (1992). Suomen aikuiskasvatuksen organisaatiomuodot. Kasvatustieteen laitos. B 7. Tampere: Tampereen yliopisto.

ALANEN, A. (1997). Aikuiskasvatuksen arvofilosofi, poleeminen individualisti, humanisti. Teoksessa J. Tuomisto \& R. Oksanen (toim.) Urpo Harva. Filosofi, kasvattaja, keskustelija. Tampere: Tampereen yliopisto, 27-36.

CASTRÉN, Z. (1929). Valtio ja vapaa kansansivistystyö. Valtioneuvostolle 24 p. heinäk. 1929 annettu mietintö. Eripainos Kansanvalistus ja Kirjastolehden n:oista 5-6 v. 1929. Helsinki: Kansanvalistusseura.

CAVONIUS, G. (1982). Tanke och gärning. Svenska folkskolan vänner 1882-1982. Borgå: SFV.

EKOLA, J. \& Vaherva, T. (1976). Aikuisopetusopas. 3. uudistettu painos. Helsinki: Tammi.

HARVA, U. (1943). Vapaa kansansivistystyö. Yhteiskunnallisen Korkeakoulun julkaisuja II. Vammala: Oy Sininen Kirja.

HARVA, U. (1958). Aikuiskasvatus. Johdatus aikuiskasvatuksen teoriaan ja työmuotoihin Suomes$s a$. Toinen, muuttamaton painos. Helsinki: Otava.

HARVA, U. (1965). Systemaattinen kasvatustiede. Kolmas, muuttamaton painos. Helsinki: Otava.

HARVA, U. (1969). Alas professorit. Kulttuuripoliittinen ajankuva Nyky-Suomesta. TJP-kirja 6. Forssa: Alea.kirja Oy.

INKILÄ, A. (1960). Kansanvalistusseura Suomen vapaassa kansansivistystyössä 1874-1959. Keuruu: Otava.

JARVIS, P. (1990). An International Dictionary of Adult and Continuing Education. London: Routledge.

KARTTUNEN, M.O. (1979). Suomen kansanopisto 1889-1979. Forssa: Suomen Kansanopistoyhdistys.

PALONEN, K. (1975). Aatevirtauksia Suomessa Snellmanista nykyaikaan. Loimaa: Opintotoiminnan Keskusliitto.

RAJANIEMI, A. (toim.) 2000. Suomalaisen ammattikasvatuksen historia. Opetus-, kasvatus- ja koulutusalojen säätiö - OKKA-säätiön ja Tampereen yliopiston Ammattikasvatuksen tutkimus- ja kou- 
lutuskeskuksen julkaisuja. Saarijärvi: OKKA-säätiö.

RASILA, V. (1986). Kriittinen humanismi aikuiskasvatuksen yleisohjeena. Teoksessa Kriittinen ajattelu aikuiskasvatuksessa. Vapaan sivistystyön XXXI vuosikirja. Pieksämäki: Kansanvalistusseura ja Aikuiskasvatuksen Tutkimusseura.

RINNE, R. \& Vanttaja, M. (1999). Suomalaista aikuiskoulutuspolitiikkaa. Muutoksia ja jännitteitä 1980- ja 1990-luvuilla. Opetusministeriön Koulutus- ja tiedepolitiikan osaston julkaisusarja. 67. Helsinki: Opetusministeriö ja Turun yliopiston kasvatustieteiden laitos.

SALMELA, M. (1998). Suomalaisen kulttuurifilosofian vuosisata. Pieksämäki: Otava.

SNELLMAN, J.V. (1901). Valtio-oppi. Kootut teokset. Viides osa. Porvoo: WSOY.

The 1919 Report. The Final and Interim Reports of the Adult Education Committee of the Ministry of Reconstruction 1918-1919. Reprinted with Introductory Essays by Wilthire, H. \& Taylor, J. \& Jennings, B. Nottingham: Department of Adult Education, University of Notttingham.

TOIVIAINEN, T. (1997) Intellektuaalisen fasadin taustaa: kansainväliset vaikutteet Urpo Harvan aikuiskasvatusajattelussa. Teoksessa J. Tuomisto \& R. Oksanen (toim.) Urpo Harva. Filosofi, kasvattaja, keskustelija. Tampere: Tampereen yliopisto, $45-76$.

TUOMISTO, J. (1989). Aikuiskasvatuksen suuri linja sivistyksellisen tasa-arvoisuuden edistäminen. Teoksessa Kriittinen ajattelu aikuiskasvatuksessa. Vapaan sivistystyön XXXI vuosikirja. Pieksämäki: Kansanvalistusseura ja Aikuiskasvatuksen Tutkimusseura.

TUOMISTO, J. (1993). Aikuiskasvatuksen perusaineksia. Tampereen yliopiston täydennyskoulutuskeskus. B 2/92. Tampere: Tampereen yliopisto.

TUOMISTO, J. \& Pantzar, E. (1997). Elinikäinen oppiminen kansallisena ja kansainvälisenä työn ja koulutuksen kehittämisstrategiana. Elinikäisen oppimisen komitean mietinnön (1997) liite. Helsinki: Edita [Tuomisto kirjoittanut luvut I-IV]

VAHERVA, T. (1995). Onko kasvatustiede edistynyt? Määritelkäämme edistyksen tuntomerkit. Aikuiskasvatus 15 (4), 265-270.

VAHERVA, T. \& Ekola, J. (1986). Aikuisten opettamisen taito. Helsinki: Yleisradio.

VIRKKUNEN, J. (1981). Matti Peltonen. Aikuisdidaktiikan perusaineksia. Aikuiskasvatus 1(2), 70-72.

WESTBROOK, R.B. (1992). John Dewey and American Democracy. Second printing. Ithaca: Cornell University Press.

WILSKA, M. (1936). Kansanopistoaatteen kehitys Suomessa vuosina 1868-1892. Helsinki: SKS.

\section{Viitteet}

1 Tämän osakysymyksen käsittelyn lähtökohdaksi sopii Rajaniemen toimittama ja OKKO-säätiön kustantama Suomalaisen ammattikasvatuksen historia (2000) ja sen kolmestakymmenestä asiantuntijakirjoituksesta erityisesti Anja Heikkisen ja Jaakko Itälän artikkelit. Perusteellisempaa tietoa saa myös mm. Jukka Tuomiston (1986) ja Anja Heikkisen (1995) väitöskirjoista.
2 Aaltonen toteaa lisäksi sen, että Snellman puhuu 2 eri kansanosien erilaisista sivistystarpeista ja käyttää luokkajakoa maanviljelijät, kauppias-porvarit ja virkamiehet. Valtio-opin ilmestyessä vuonna 1842 työväestöä ei vielä hahmotettu selkeäksi ryhmäkseen.

3 Näin mm. Peter Jarvis (1990, 97) sekä Cross3 Durant artikkelissaan "John Dewey and Lifelong Education" Peter Jarvisin toimittamassa teoksessa Twentieth Century Thinkers in Adult Education. London: Croom Helm 1987.

\section{Toimitus kommentoi}

I Rasila ei saa kunniaa yksin. Jukka Tuomisto on ainakin kerran käyttänyt ajanjaksojen luonnehdinnassa jaottelua valistus, sivistys ja kasvatus. Näin tapahtui silloin, kun vapaan sivistystyön XXXII vuosikirja työnimeltään Aikuiskasvatuksen klassikoita (1991) sai hänen toivomuksestaan lopulliseksi nimekseen Valistus, sivistys, kasvatus. Klassikoiden tekstit on teoksen sisällä luokiteltu kuitenkin omanlaisensa logiikan mukaan. Vuosikirjan toisena toimittajana oli JT:n lisäksi Rainer Aaltonen.

II Kaksipäiväinen tutkijatapaaminen kirjoittajan luettelemin tavoittein toteutui tänä syksynä 12 .13. lokakuuta. Mitä jäi haaviin? 1990-luvun kotimainen aikuiskasvatustutkimus ja sen haasteet 2000luvulle -nimisessä tutkijatapaamisessa analysoitiin menneen vuosikymmenen aikuiskasvatustutkimusta, esiteltiin parisenkymmentä käynnistyvää tai käynnissä olevaa tutkimusta sekä yritettiin joukolla katsoa tulevaisuuden odotuksiin ja tutkimustarpeisiin. Mukana oli myös puheenvuoron kirjoittaja, joka oli siellä vapaan sivistystyön ja historian ryhmän vastuuhenkilönä. Aikuiskasvatuksen Tutkimusseuran järjestämään tutkijatapaamiseen osallistui toista sataa henkilöä. Siitä ilmestyy myöhemmin myös oma julkaisunsa. Tässä Aikuiskasvatuksen numerossa on tapaamisesta pieni maistiainen sivulla 378 . 